\title{
Spatial Organization of High Schools in Goa
}

\author{
Ms. Arati Panshekar \\ Assistant Professor in Govt. College of Arts, Science and Commerce Sanquelim, Goa
}

\begin{abstract}
Spatial organization of physical and cultural features on the earth's surface can be analysed by geographical investigation. This paper studies spatial distribution pattern of high schools in different tehsils of Goa. The spatial patterns of high schools in Goa are characterized by their uneven distribution due to physical and cultural factors. More concentrations of high schools are found in urban areas and more dispersion is noticed in rural areas where the population density is low. Statistical techniques are used to analyse and identify the central tendency and dispersion of high schools in different tehsils of Goa.
\end{abstract}

Key words: High schools, Central tendency, Dispersion, Spatial distribution

\section{INTRODUCTION}

Government make education accessible to each and every individual as it is one of the driving force for the socio-economic development of the region. Educational institutions are typically concentrated in settlement areas. More number of educational centres of different hierarchy is found in cities due to more population, whereas rural areas are equipped with lesser number of educational institutions. Thus an urbanized area seems to have better educational facilities than rural areas. Administratively the region is consisting of 11 tehsils. There are 399 high schools in all tehsils(Education, 2010-11). The distributional patterns of these high schools are not uniform. Spatial pattern is uneven due to social, political and physiographic elements influencing distribution. A physiographic element includes topography, forest cover area and altitude. Social elements involve the concentration of settlements in the region. The location of schools should be based on factors like the population and proximity of the region.

\section{STUDY REGION}

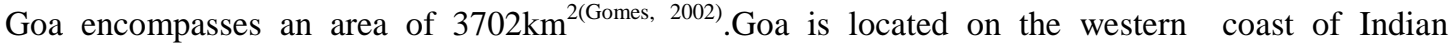
peninsular, separated from Maharashtra in the north, Karnataka in the south, the western Ghats in the east \& the Arabian sea in the west. Geographically the position of Goa is between the latitudes $15^{0} 40^{\prime} 00^{\prime}$ North to $14^{0} 53^{\prime}$ '54" North and longitude $74^{\circ} 20^{\prime} 13^{\prime \prime}$ 'east to $73^{\circ} 40^{\prime} 33^{\prime \prime}$ east. According to the 2011 census, Goa has a literacy rate of $87 \%$, with $90 \%$ of males \& $84 \%$ of females being literate (Primary Census Abstract, 2011). All schools in Goa come under the Goa Board of Secondary \& Higher Secondary Education, whose syllabus is prescribed by the state education department. There are also a few schools that subscribe to the all-India ICSE syllabus or the NIOS syllabus. Most of the students in Goa complete their high school with English as the medium of instruction.

\section{OBJECTIVES}

1. To find out central tendency and dispersion of high schools in Goa.

2. To analyse the spatial distribution pattern of schools in Goa.

\section{METHODOLOGIES}

The mean centres for the high schools in all 11 tehsils are measured according to their spatial distribution. The geographic mean is the centre point of the region. Standard deviation is considered as standard distance to measure the degree of dispersion of all points from the mean centre. It measures the absolute dispersion or variability of a distribution, the greater the amount of dispersion or variability, the greater the standard deviation. Standard distance is calculated by using following formula, (V.K.Kapoor, 1992) $\mathrm{SD}=\sqrt{ }\left\{\sum \mathrm{x}^{2} / \mathrm{n}-\left(\sum \mathrm{x} / \mathrm{n}\right)^{2}\right\}$

Where, $\mathrm{SD}=$ Standard distance

$\mathrm{n}=$ no. of high schools

$\mathrm{x}=$ distance of each centre from mean centre. 


\section{LIMITATIONS OF THE STUDY}

For the present study only high schools are selected to analyse their spatial distributional pattern. Other elementary schools, higher secondary schools and colleges are not taken into consideration. The study is focused on 11 tehsils of Goa and the Dharbandora is not included in the study as a different tehsil because it is carved out recently from Sanguem tehsil. Hence, study is carried out in entire Sanguem. Another reason for taking entire Sanguem tehsil is lack of data available for Dharbandora tehsil separately.

\section{CENTRAL TENDENCY AND DISPERSION OF HIGH SCHOOLS IN GOA}

The spatial distributional patterns of high schools in Goa are characterized by their uneven distributions which are shown with the point pattern. Mean centre of all high schools in the region is measured and it is located in western part of Ponda. The geographic centre of the region is also demarcated with the help of coordinate system and it is in southern part of Ponda tehsil. From mean centre the circle is drawn taking radius as standard distance. The main feature of this circle is that it will comprise $2 / 3^{\text {rd }}$ that is approximately $66.66 \%$ of the total number of points i.e. high schools in the region which will depict that the region has normal distribution of high schools (Mali, 2011).There are 399 high schools in Goa (Education, 2010-11). Out of which 73 schools comes under drawn circle from the mean centre of all high schools. It makes $18.2 \%$ of total high schools in Goa, which clearly shows that the pattern of high school distribution is not normal. Maximum dispersion of high schools is noticed in the eastern parts of Goa, where the population concentration is lesser due to hilly terrain with vegetation which is a part of western ghat. More concentrations of schools are found in the coastal areas and urban areas due to high density of population. Terrain and population are the important factors affecting the distribution of high schools in Goa.

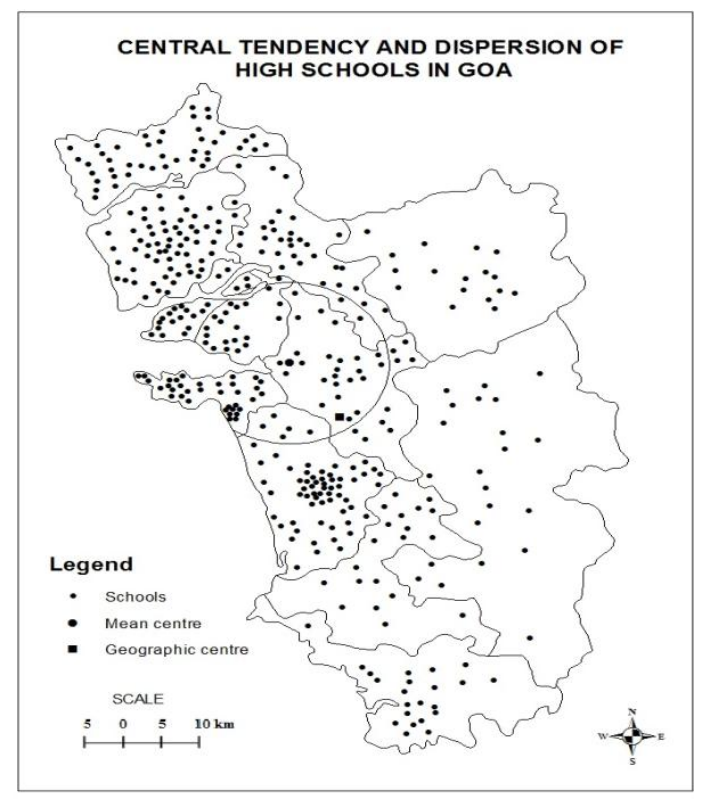

Fig No- 1

Table No: 1 - Total Numbers of high schools in Goa

\begin{tabular}{|c|c|c|c|c|}
\hline Sr.No. & Tehsil & $\begin{array}{c}\text { Total No. of } \\
\text { high schools }\end{array}$ & $\begin{array}{c}\text { No. of high schools } \\
\text { in marked circle }\end{array}$ & $\begin{array}{c}\text { \% of high } \\
\text { schools in a } \\
\text { circle }\end{array}$ \\
\hline 1 & Bardez & 61 & 20 & 98.36 \\
\hline 2 & Canacona & 22 & 9 & 40.90 \\
\hline 3 & Murmugao & 36 & 2 & 5.55 \\
\hline 4 & Pernem & 43 & 5 & 11.62 \\
\hline 5 & Quepem & 20 & 3 & 15 \\
\hline 6 & Satari & 17 & 3 & 17.64 \\
\hline 7 & Ponda & 35 & 12 & 34.28 \\
\hline 8 & Salcete & 66 & 31 & 46.96 \\
\hline 9 & Bicholim & 33 & 16 & 48.48 \\
\hline 10 & Sanguem & 23 & 3 & 13 \\
\hline 11 & Tiswadi & 43 & 3 & 6.97 \\
\hline
\end{tabular}


CENTRAL TENDENCY AND DISPERSION OF HIGH SCHOOLS

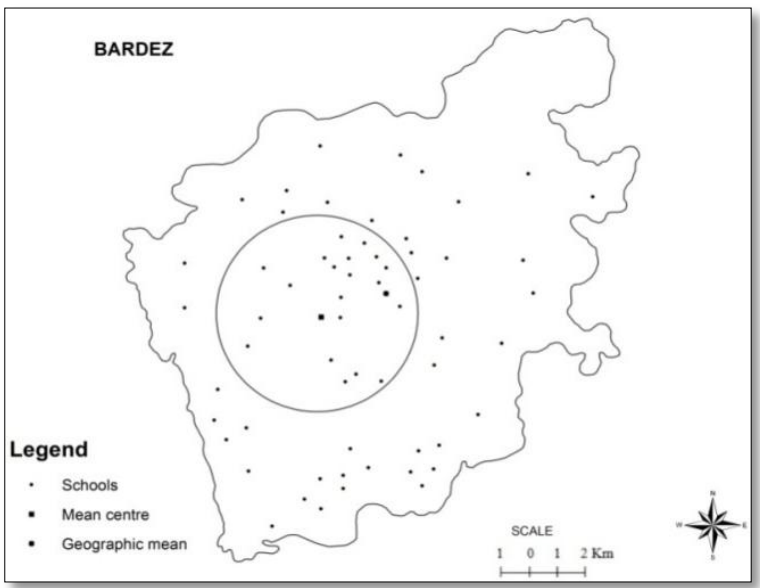

Fig No- 2

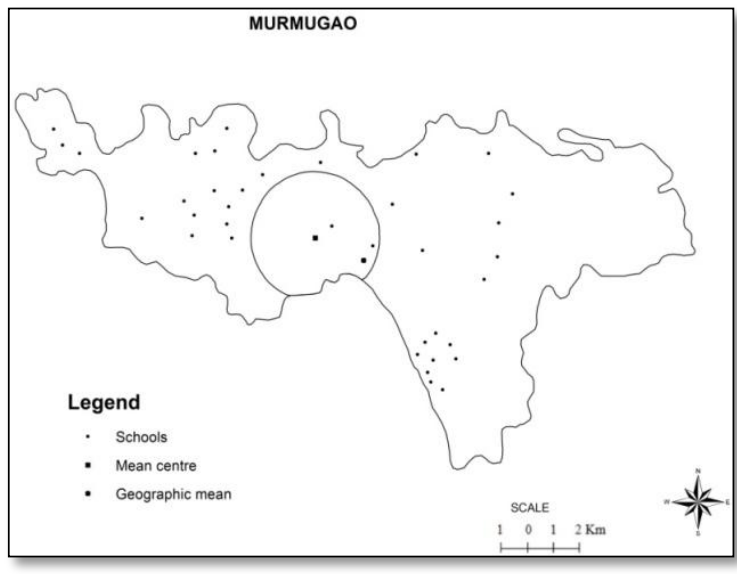

Fig No- 4

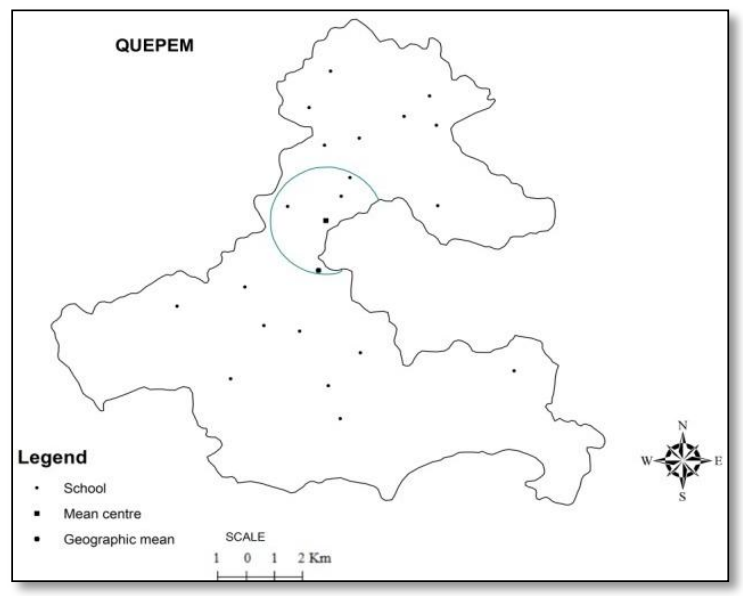

Fig No- 6

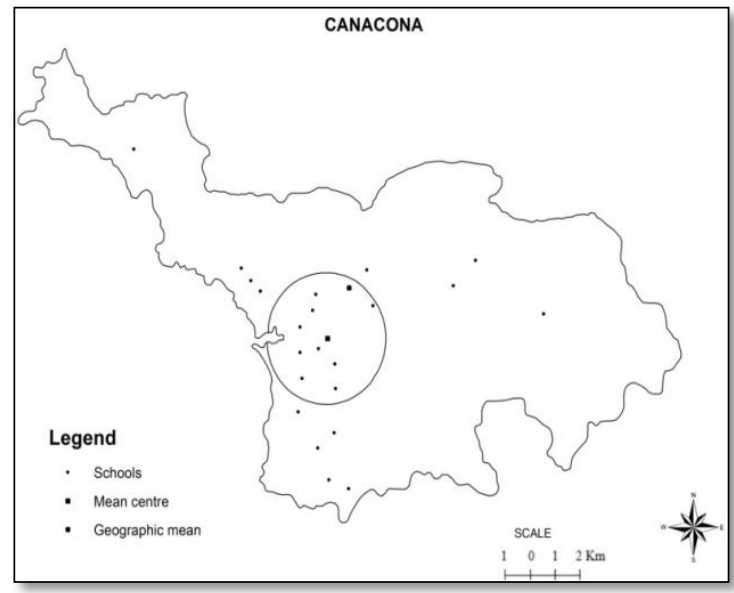

Fig No- 3

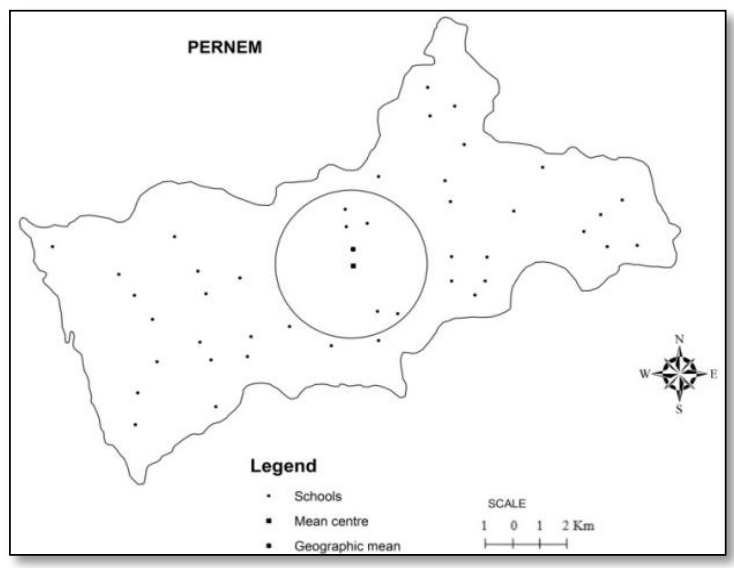

Fig No- 5

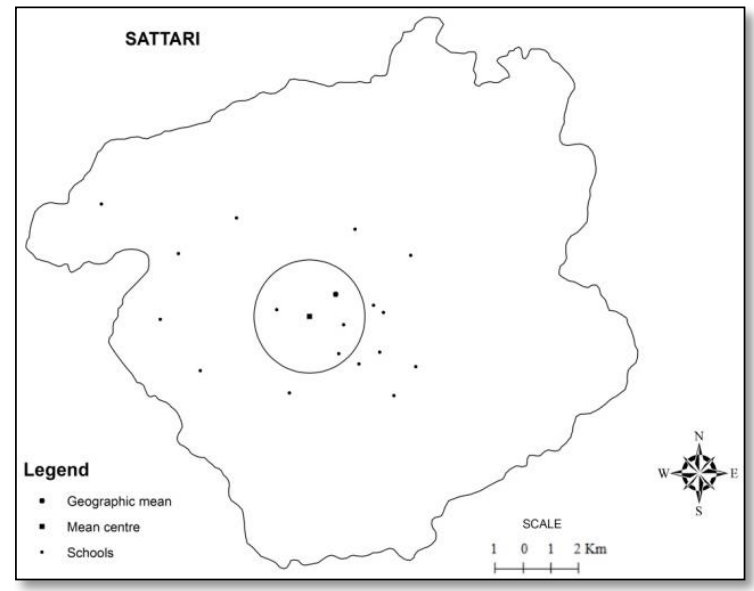

Fig No- 7 


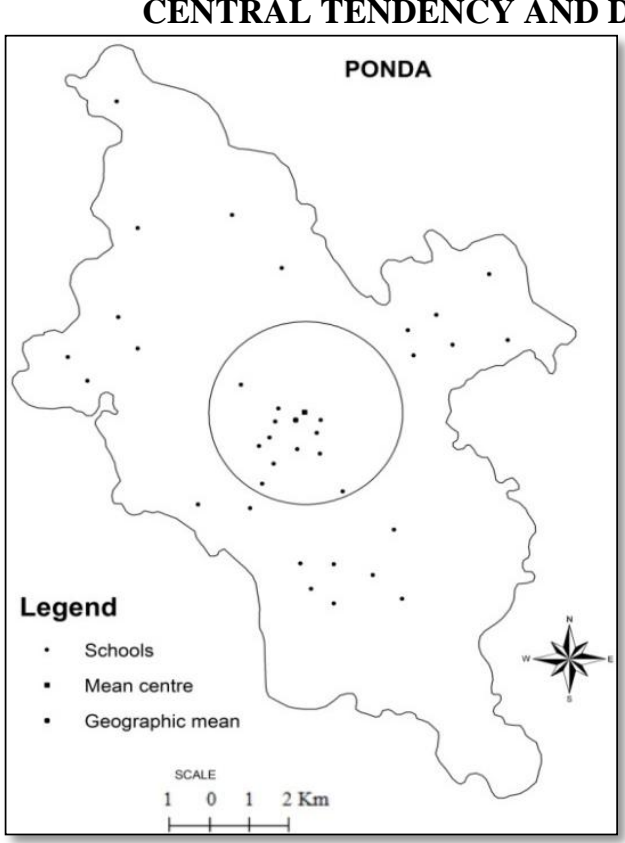

Fig No- 8

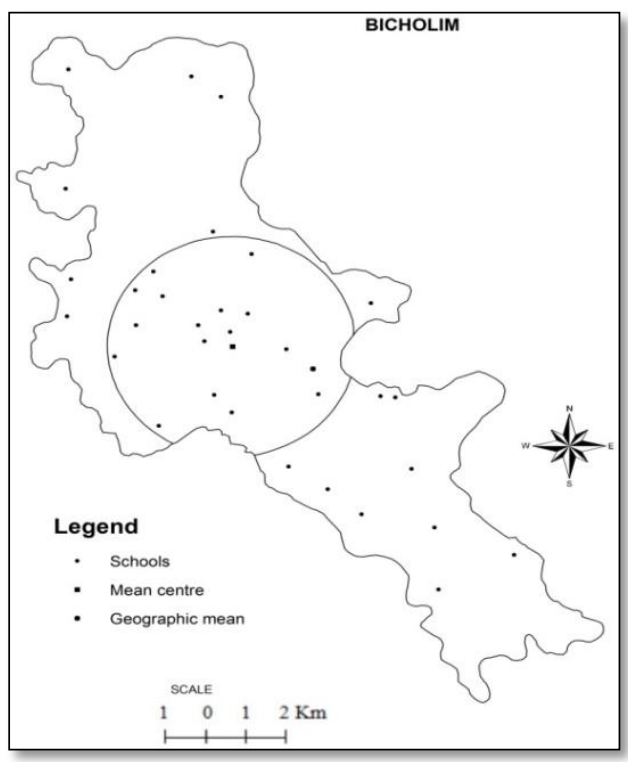

Fig No- 10

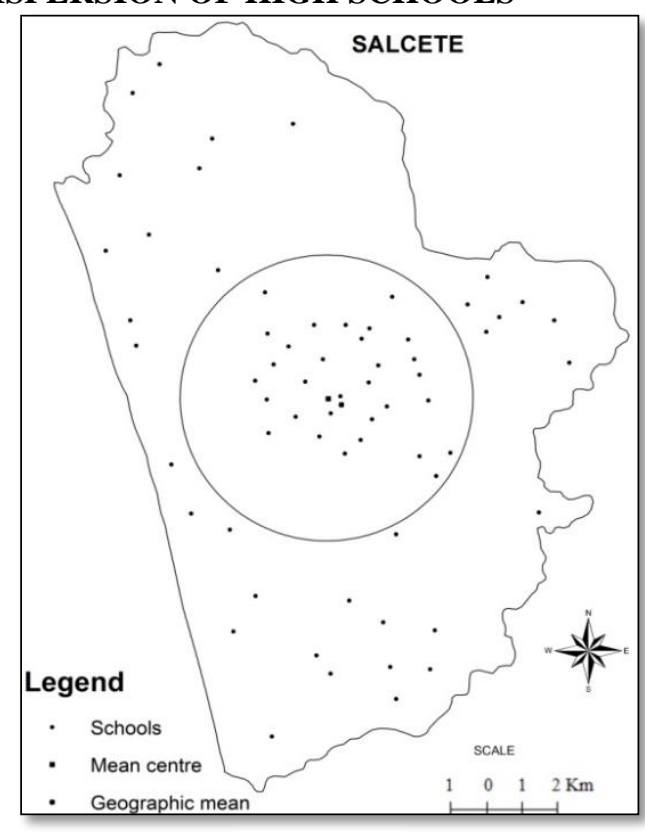

Fig No- 9

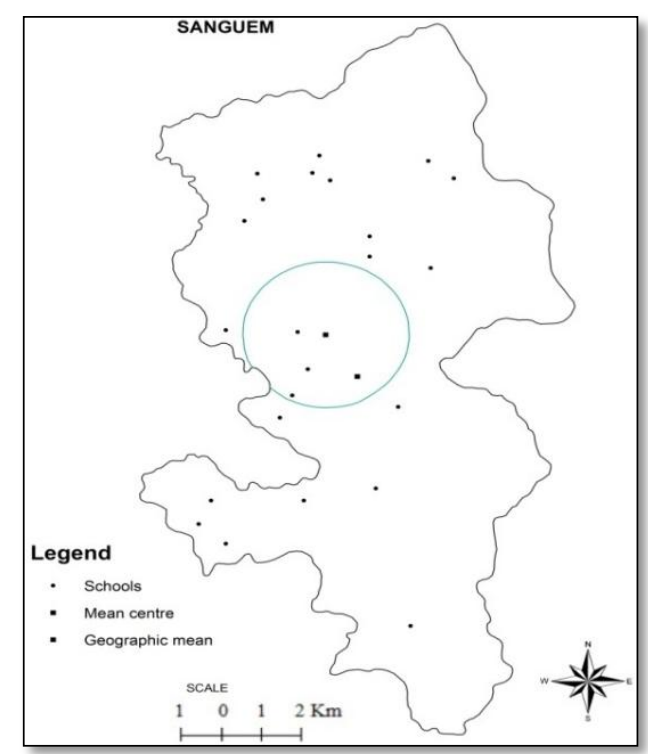

Fig No- 11

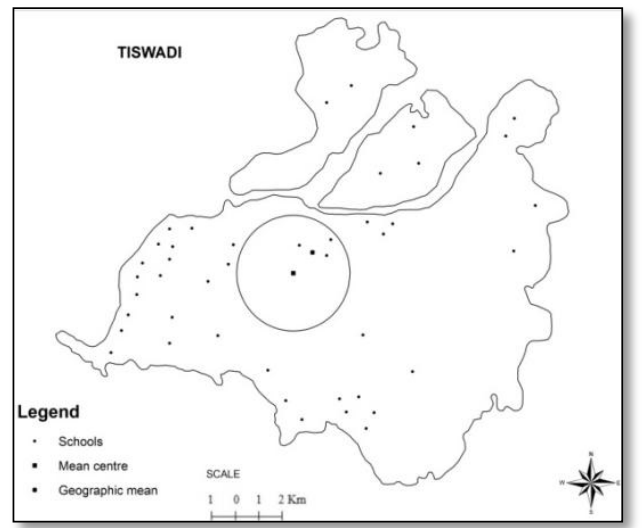

Fig No- 12 


\section{CENTRAL TENDENCY AND DISPERSION OF SCHOOLS IN BARDEZ TEHSIL}

Bardez is delimited on the north by the Chapora river, on the south by the Mandovi river, on the east by the Mapusa river and on the west by the Arabian Sea. The total area of Bardez is $213.57 \mathrm{~km}^{2}$ (Goa, 1997-98). According to 2011 census the total population of the region is 237440 persons (Primary Census Abstract, 2011) with density of 899 persons per square kilometer. The total literacy rate of Bardez is $82.55 \%$ (Primary Census Abstract, 2011). Fig.2 indicates the spatial distributions of high schools in Bardez .There are 61 high schools in Bardez. The geographic mean of the tehsil is in Mapusa. The mean centre of spatial distribution of high schools is located in Mapusa, which clearly shows that the most of the high schools are located in Mapusa region. Spatial pattern of high schools shows 20 high schools out of 61 are located within the marked circle, which is drawn from the mean centre of all high schools using standard distance. Higher concentration of schools is found in Mapusa, where the density of population is very high and it is one of the urbanized and industrialized areas in Goa. The concentration of high schools seems to be very less in village areas such as Pirna, Nadora, Revona etc. This is because of lesser population and settlements in these areas. Hence the distributions of high schools are not uniform.

\section{CENTRAL TENDENCY AND DISPERSION OF SCHOOLS IN CANACONA TEHSIL}

Canacona lies in southern part of Goa. Canacona is an administrative region in south Goa. It is bounded on the north by Quepem, on the northeast by Sanguem, on the south by the state Karnataka and on the west by the Arabian Sea. The town of Chaudi is the administrative headquarter of the tehsil. Total area of Canacona is 352.02sq km (Goa, 1997-98). According to census 2011 Canacona has a population about 45,172(Primary Census Abstract, 2011). Male constitute about 22532 of population and female constitute of about 22640 of the population(Primary Census Abstract, 2011).Canacona has average literacy of 75.89\%(Primary Census Abstract, 2011).The total numbers of high schools in the tehsil are 22 and out of which 9 high schools are located within the circle marked, which makes $40.90 \%$. It clearly shows the patterns of distribution of schools are not normal and uniform. More number of high schools are oriented towards the western part of the tehsil. In the eastern part of the region such as Endrem, Bhutpal, Nadquem, Anvalietc, the concentration of high schools are very less. It is because the region forms a part of western ghat with dense forest and difficult terrain, where there is limited scope for human settlements.

\section{CENTRAL TENDENCY AND DISPERSION OF SCHOOLS IN MORMUGAO TEHSIL}

Mormugao is a sub-district and a municipal council in south Goa district. It has an average elevation of 2 metres from mean sea level. According to 2011 census the population of Murmugao is 154561, with 81138 males and 73423 females. The density of the tehsil is 1416 person per $\mathrm{km}^{2}$ (Goa, 1997-98), which is highest among all tehsils. The literacy rate is $85.16 \%$ (Primary Census Abstract, 2011).The geographic mean and the mean centre of spatial distribution of high schools in tehsil is located in Issorcim. There are 36 high schools in the tehsil, out of which only 2 high schools are located within the marked circle from the mean centre by taking standard distance. It makes only $5.55 \%$ which clearly indicates that the spatial distributions of high schools are not normal. The distribution is in clusters. More concentration is found in mormugao MCI, Velsoa and Cansaulim. Mormugao is one of the most developed and urbanized area due to port facilities. As there is lot of scope for economic activities, Mormugao is the tehsil with highest density. To serve this densely populated area there is need of more number of schools. Eastern areas of the tehsil shows dispersed distributional pattern of high schools.

\section{CENTRAL TENDENCY AND DISPERSION OF SCHOOLS IN PERNEM TEHSIL}

Pernem is a northern most administrative tehsil in North Goa. Geographically, it is surrounded by Bicholim tehsil on East, Arabian Sea on west, Bardez tehsil on South and Sawantwadi tehsil on North. According to 2011 census the total population of Pernem is 75747(Primary Census Abstract, 2011), with the density of 300 persons per square kilometre. The tehsil has $80 \%$ of literacy rate (Primary Census Abstract, 2011). There are 43 high schools in the tehsil. The mean centre of this distribution is located in Pernem MCI. Out of 43 schools 5 schools (11.62\%) are located in the marked circle. It clearly indicates that the spatial distributional patterns of high schools in the tehsil are not uniform and even. More concentrations of high schools are found in the western part of tehsil which are census towns. Eastern part of tehsil shows dispersed pattern of high schools which is due to low density of population in the region due to presence of reserved forest area such as Imbrampur RF, Alarna RF, Chandel RF, Cansorvorem RF, Mopa RF, Tamboxem RF which hinders the development of settlements in the region. 


\section{CENTRAL TENDENCY AND DISPERSION OF SCHOOLS IN QUEPEM TEHSIL}

Quepem is locatedat an average elevation of 21 meter from mean seal level. As of the 2011 census, it had a population of 81193(Primary Census Abstract, 2011). Quepem has an average literacy rate of 74\%(Primary Census Abstract, 2011).Quepem MCI is the mean centre of spatial distribution of high schools and geographic mean is in Adnem. 20 out of only 3 schools are marked in the circle, which makes $15 \%$. It shows highly uneven distribution of high schools in Quepem. More concentration is noticed in central part and lesser concentrations of schools are seen in extreme southern part of the tehsil, which are rural areas with lesser density of population.

\section{CENTRAL TENDENCY AND DISPERSION OF SCHOOLS IN SATTARI TEHSIL}

Sattari is a part of western ghat. River mhadei flows through this region. Valpoi is the administrative centre of the tehsil. According to 2011 census the total population of Sattari is 63817 with population density 129 persons per square kilometre(Primary Census Abstract, 2011).The literacy rate of the tehsil is 76\%(Primary Census Abstract, 2011).The total numbers of high schools in the region are17, its distributional pattern is shown in fig.4. The mean centre for all points is in Valpoi. Out of 17 only 3 schools are marked in a circle, which is drawn from the mean centre by using calculated standard distance. It makes $17.64 \%$ which clearly shows that the distributional pattern is uneven. Higher concentration of schools are found in Valpoi, as it is the only urbanized area and the administrative centre of the tehsil, where the population density is very high, which is directly proportional to the number of schools in the region. The locations of high schools are more dispersed in the extreme northern, eastern and southern part of the tehsil, where the settlements are more scattered due to hilly terrain and dense vegetation. These are the rural areas with thin population density and this small population is being served by the high schools which are scattered and randomly located in the region.

\section{CENTRAL TENDENCY AND DISPERSION OF SCHOOLS IN PONDA TEHSIL}

Ponda also known as Fonda, located in central part of the state. It is one of the industrial centres of the state. It is home to many large factories and industrial estate and is fastest growing city. It has an average elevation of 42 metres from mean sea level. It lies along the National Highway 4A which connect the Belgaum to Panaji and other neighbouring state of Karnataka. According to the2011 census of India, Ponda had 165830 population with density of 566 persons per square kilometre (Primary Census Abstract, 2011).The literacy rate of Ponda is $80.70 \%$ (Primary Census Abstract, 2011). Ponda is the geographic mean and mean centre of the distributional points of schools in the tehsil. There are 35 schools out of which 12 schools are marked in the circle, which makes $34.28 \%$ of the distribution. It shows that the distribution pattern of high schools in Ponda is not normal. More concentration of schools are found in Ponda, Bandora, Quela, Borim, Curti, Priol and Usgao ,as these are urban and census towns where the population density is very high due to number of economic opportunities available in the region. Dispersed distributional pattern of high schools are found in northern and southern part of the region where settlements are lesser in number as it makes part of rural areas.

\section{CENTRAL TENDENCY AND DISPERSION OF SCHOOLS IN SALCETE TEHSIL}

The total area of Salcete is $292.94 \mathrm{~km}^{2}$ (Goa, 1997-98). According to 2011 census the total population is 294464 (Primary Census Abstract, 2011)with density 1005 person per square kilometre. The total literacy rate of the region is $80.17 \%$ (Primary Census Abstract, 2011). There are 66 high schools in Salcete. The calculated mean for spatial distribution of high schools is in Aquem. 31 high schools, which make 46.96\%, are enclosed in the marked circle which clearly indicates the uneven distributional pattern of high schools. High concentration of schools are found in the Margoa and nearby areas such as Raia, Curtorim and Sao jose de, which are parts of urban areas. Dispersed and scattered distribution is noticed in Loutulim, Camurlim, Mulem, Sarzana, etc which are rural areas.

\section{CENTRAL TENDENCY AND DISPERSION OF SCHOOLS IN BICHOLIM TEHSIL}

Bicholim is in the mining heartland of Goa. As of 2011 India census, Bicholim had a population of 16,986(Primary Census Abstract, 2011) with population density of 410 person per square kilometre. Set up by the Goa Industrial Development Department, the Bicholim Industrial Estate located on the banks of Mandovi tributary is home to more than 50 industrial work and manufacturing units specializing in a range of products and services such as Pottery, mining equipments, plastics etc. It has an average literacy rate of $82 \%$ (Primary Census Abstract, 2011). Fig.10 shows spatial distribution of high schools is Bicholim. The mean centre of the distribution is located in Bicholim (MCI). 16 high schools out of 33 are located within circle, which makes approximately $48 \%$ of the total number of high schools in the region. Maximum concentration of high schools are found in central part of the region, i.e., in Bicholim and its surrounding area, as it makes part of urbanized area where the population density seems to be higher. Pattern of distribution is more dispersed in extreme northern and southern part of the tehsil, which are rural areas, where the population density is lesser. Areas such 
as Latambarcem, Surla and Cotambi have very low concentration of schools as it makes part of mining area and Salem, Latambarcem reserved forest area where the human settlements are sparsely distributed.

\section{CENTRAL TENDENCY AND DISPERSION OF SCHOOLS IN SANGUEM TEHSIL}

Sanguem is located at $15.23^{\circ} \mathrm{N}$ latitude and $74.17^{\circ} \mathrm{E}$ longitude. It has an average elevation of 22 meters from mean sea level. It covers an area of about $873.75 \mathrm{~km}^{2}$ (Goa, 1997-98). As of 2011 India census Sanguem had a population of 65147(Primary Census Abstract, 2011). It has a literacy rate of 74.39\%(Primary Census Abstract, 2011), which is lower than the state average of $88.70 \%$ (Primary Census Abstract, 2011). The population density of Sanguem is 74 persons per square kilometre. The eastern part of the tehsil forms the part of western ghat. Total numbers of high schools in Sanguem are 23, out of which only 3 schools that make $13 \%$ of total distribution are located in the marked circle, which clearly shows that the distributional pattern of the high schools in the region is not normal. The high schools have dispersed location due to low density of the population which are directly influenced by the undulating topography with forest cover.

\section{CENTRAL TENDENCY AND DISPERSION OF SCHOOLS IN TISWADI TEHSIL}

It is geographically an island with the Mandovi River forming its northern boundary. It includes the smaller islands of Chorao, Divar, St Estevam, Cumbarjua and Vanxim. The total area of Tiswadi is $213.57 \mathrm{~km}^{2}$ (Goa, 1997-98). According to 2011 census the population of tehsil is 177219 (Primary Census Abstract, 2011)persons. The population density is 829 persons per square kilometre. The total literacy rate of the region is $81.82 \%$ (Primary Census Abstract, 2011).Spatial distribution of high schools, its geographic centre and mean centre are shown in the fig.12.The mean centre is located in Marces and the geographic centre is in Chimbel. The pattern of distribution is dispersed in south-east part of the region, which forms a part of village area where the population is comparatively lesser. These areas include Ella, Golimmoula, Mandur, Neural-oGrande, Curca etc. There are 43 schools in Tiswadi, out of which only 3 schools are enclosed in the marked circle which makes $6.97 \%$. It clearly indicates that the distribution of high schools in the region is not normal. High concentrations of schools are found in Panjim, Taleigao, Vella Goa etc, which are urban areas and census towns where the density of population is very high.

\section{CONCLUSION}

Accessibility is the important factor for the location of schools. Accessibility refers to the distance an individual must cover to receive the desire service. Education is an important part of the public facilities, which is very essential for the social and economic development. There are 399 high schools identified in the region across all 11 tehsils. The study shows that most of the high schools are located in urban areas, which is urban biased as a result of high population density. City areas such as Mapusa, Ponda, Panaji, Margao, have higher concentration of schools. Though there are some geographical factors responsible for the development of settlements such as physiography of the region and forest cover area, which are directly responsible for the emergence of schools in a region. Some areas are well served, marginally served, and underserved by the high school facilities. As we can see the urban biasness in the distributional pattern of the high schools, it is therefore important that government and other private stakeholders strive to ensure the distribution of schools across the region for easy accessibility of schooling facility to each and every individual without any hindrance or any bias agenda.

\section{REFERENCES}

[1] Education, D. o. (2010-11). List of Recognised Educational Institutions. Panaji Goa: Directorate of Education Statistics Section, Government of Goa.

[2] Goa, G. o. (1997-98). Statistical Handbook of Goa. Panaji,Goa: Directorate of Planning, Statistics and Evaluation.

[3] Gomes, O. (2002). Goa. New Delhi: The Director,National Book Trust ,India.

[4] Mali, D. K. (2011). Spatial organization of holy places in Maharashtra. Research paperGeography, 154163.

[5] (2011). Primary Census Abstract. Goa.

[6] V.K.Kapoor, D. C. (1992). Statistics-Theory, Methods and Application. New Delhi: Sultan Chand \& Sons. 